REGE

26,3

198

Received 6 January 2018 Revised 6 November 2018 23 November 2018 1 March 2019 16 April 2019 Accepted 30 April 2019

\section{Purchase intention of organic food under the influence of attributes, consumer trust and perceived value}

\author{
Isabelle Cristina Galindo Curvelo \\ Universidade de Sao Paulo, Sao Paulo, Brazil, and \\ Eluiza Alberto de Morais Watanabe and Solange Alfinito \\ Universidade de Brasilia, Brasilia, Brazil
}

\begin{abstract}
Purpose - The consumption of organic food increases worldwide, which raises the need for studies that try to understand the variables that affect the consumption of this kind of food. The purpose of this paper is to analyze the influence of attributes, consumer trust and perceived value on purchase intention of organic food. Design/methodology/approach - A descriptive quantitative research was conducted through a survey of 247 valid cases of organic food consumers. For the purposes of analysis, exploratory factorial and linear regression analyzes were chosen.

Findings - Exploratory factor analysis showed that all tested constructs were valid for the Brazilian context. Linear regression analyses showed that emotional value, consumer trust and the attribute "sensory appeal" affect the purchase intention of organic food. Emotional value had a stronger relationship and sensory appeal showed a negative relationship with purchase intention.

Practical implications - Research results can help managers increase the likelihood of buying organic foods through strategic marketing management focused on emotional value and sensory appeal factors.

Originality/value - The study offers value to the study of organic foods in view that this theme is not much explored in the Brazilian scenario even with the market in an increasing pattern, as well as the combination of perceived value, attributes, trust and purchase intention as variables in a single prediction model.
\end{abstract}

Keywords Organic food, Sensory appeal, Trust, Perceived value, Purchase intention

Paper type Research paper

\section{Introduction}

Sustainability has been widely discussed in the current global scenario, thanks to people's growing ecological awareness and the emergence of pro-environmental movements (Bamberg \& Möser, 2007). This has strengthened consumers' wish and need to get products that match this new perspective (Aertsens, Mondelaers, Verbeke, Buysse, \& Van Huylenbroeck, 2011). They are consumers increasingly aware of the consequences of their consumption acts, which form a segment called "green market," or the green consumer's market (Peattie, 2010). In the food sector, there is a significant increase of the demand for organic products. They are consumers who continually incorporate these products into their daily eating habits (Aschemann-Witzel \& Hamm, 2010). This is explained by their changes of attitude, beliefs, values and motivations, and by a more critical position regarding food safety and the consumption of processed food (Wilcock, Pun, Khanona, \& Aung, 2004; Nocella \& Kennedy, 2012).

In this context, the organic food market, which is the focus of this paper, is one of the fastest growing markets in recent years in several countries, including Brazil. Organic food

(C) Isabelle Cristina Galindo Curvelo, Eluiza Alberto de Morais Watanabe and Solange Alfinito. Published in Revista de Gestão. Published by Emerald Publishing Limited. This article is published under the Creative Commons Attribution (CC BY 4.0) licence. Anyone may reproduce, distribute, translate and create derivative works of this article (for both commercial and non-commercial purposes), subject to full attribution to the original publication and authors. The full terms of this licence may be seen at $\mathrm{http}: / /$ creativecommons.org/licences/by/4.0/legalcode

The authors would like to thank CNPQ for research funding. 
is produced in 170 countries around the world. Global sales of organic food and beverages reached US $\$ 72 \mathrm{bn}$ in 2013. Brazil is one of the main producers and the largest consumer market for organic food in Latin America (Willer \& Lernoud, 2016).

Despite this increase, the number of studies with consumers of organic food is still small (Hsu, Chang, \& Lin, 2016; Nandi, Bokelmann, Gowdru, \& Dias, 2016). It is even smaller regarding consumers' intention to buy organic food, which is very relevant in this emerging market. It addresses the possibility of planning a purchase or the willingness to really buy a product in the future (Yin, $\mathrm{Wu}, \mathrm{Du}, \&$ Chen, 2010).

Therefore, our objective was to evaluate the influence of different aspects on consumer purchase intention of organic food. These aspects are the attributes of organic food, consumer trust in organic food and its perceived value.

Its attributes deserve attention, since there is empirical evidence that consumers of organic food find it healthier, with higher nutritional content, safer and more sustainable, when compared to conventional food (Hoppe, Vieira, \& Barcellos, 2013; Marian \& Thøgersen, 2013). In other words, it is a product with special attributes, which can be determining for consumer purchase intention.

Regarding consumer trust, it can also affect the purchase intention significantly, since the lack of consumer trust has a strong negative effect on purchase behavior of organic food (Pivato, Misani, \& Tencati, 2008; Nuttavuthisit \& Thøgersen, 2017). Thus, as highlighted by Krystallis and Chryssohoidis (2005), it is a market that considers trust as its main value. Hence, trust is associated with the perceived value of a product by the consumer, and is the last element we chose to investigate in this study.

Perceived value is the result of an assessment made by the consumer, and of the sacrifices incurred in the exchange for the benefits achieved from the purchase of a particular product (Zeithaml, 1988; Slater \& Narver, 2000; Sirdeshmukh, Singh, \& Sabol, 2002). We specify these aspects and the others previously mentioned in the next section.

\section{Theoretical background}

\section{Purchase intention}

Purchase intention is based on a study between consumer behavior and his/her intentions, which makes this construct very important for consumer research (Ghalandari \& Norouzi, 2012). Intention is a relevant dimension in marketing literature, used by companies to predict sales of new products or the repeated purchase of existing products (Diallo, 2012), and it shows the consumer trend to buy goods or services in the same store, and share his/her experience with friends and family (Cronin, Brady, \& Hult, 2000).

With regard to organic products, purchase intention can be affected by several elements, such as health perception, environmental awareness, product availability, perceived quality, product distribution, nutritional value, among others. Rana and Paul (2012) pointed out that not only the health factor affects the purchase intention, but also the availability and quality of these products. Iyer, Davari, and Paswan (2016 ) studied the relationship between purchase intention and variables such as price, value, social awareness and environmental awareness of green products. However, only environmental awareness was directly associated with purchase intention, confirming the results of Yadav and Pathak (2016). Maichum, Parichatnon, and Peng (2017) identified that, in addition to environmental awareness, knowledge and attitude toward the environment positively affect the intention to buy green products.

Liang (2016) investigated other relationships between the purchase intention of organic food and properties, certification mechanisms, retail channels and prices of these products. He observed that factors such as certification, retail channel, nutritional value and environmental protection have a positive impact on the purchase intention. As for the price, where organic products were cheaper, consumers showed more concern for product certification. Thus, consumers emphasize trust in the store or the supermarket where such products were purchased.

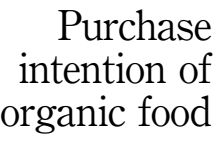

199 
REGE

26,3
Mainardes, Araujo, Lasso, and Andrade (2017), in a research conducted in Brazil, investigated the relationship between personal values and attitudes and the purchase intention of organic food, and found a positive influence of values related to conservatism, self-promotion and openness to change regarding the purchase behavior toward this kind of food.

Therefore, it is important to understand the purchase intention of organic food. The most relevant aspects identified herein were consumer trust, the perceived value of the product, along with its attributes. Hence, we chose these variables for the research, which are described below.

\section{Consumer trust}

Consumer trust is defined as a belief, feeling, or expectation about the trading partner's loyalty, which results from his/her intention, integrity or competence (Moorman, Zaltman, \& Deshpandé, 1992). When we transfer this concept into the organic food scenario, it adds trust in products and in certification.

Organic certification is based on aspects related to the preservation and regeneration of ecosystems and people and indicates that production must be accomplished without the use of pesticides and other chemical materials (Barrett, Browne, Harris, \& Cadoret, 2002). In Brazil, the most relevant certificates are Organic Brazil, from Instituto Biodynamica, and Ecocert (Machado \& Viana, 2011).

Trust in organic food is difficult to assess. This is due to the absence of visible characteristics of the product at the time of purchase, so the consumer can only rely on the seals and certifications that are tagged on the products (Kohlraush, Campos, \& Selig, 2004). Wrong or insufficient knowledge about the production process and the certification standards can lead the consumer to perceive no difference between a certified and a non-certified product (Janssen \& Hamm, 2012). It is worth mentioning that certification sources and certification systems affect consumer trust and purchase intention, as Sønderskov and Daugbjerg (2011) and Liang (2016), respectively, observed.

Regarding the influence of consumer trust on purchase intention, Teng and Wang (2015) found a positive and significant relationship between these two constructs in a study carried out in Taiwan. On the other hand, Nuttavuthisit and Thøgersen (2017) tested the theory of planned behavior by including trust in the structural model. Results also suggest that trust positively affects consumer purchase intention.

\section{Perceived value}

Perceived value is a complex concept, and there is no consensus in the literature on its definition and characteristics (Sánchez-Fernández \& Iniesta-Bonillo, 2007). One of them is that perceived value involves a general assessment made by the consumer regarding the utility of a product or service, based on the perceptions of what is received and what is paid for (Zeithaml, 1988).

According to Sweeney and Soutar (2001), perceived value has four dimensions: functional value - utility that the consumer perceives when making a choice that will bring $\mathrm{him} /$ her practical or utilitarian results; economic value - financial value involved in the exchange; social value - related to social acceptance in a given reference group, due to the choice made; and emotional value - related to positive emotional aspects derived from the choice made. We adopted herein these four dimensions of perceived value.

In a review by Shaharudin, Pani, Mansor, and Elias (2010), the perceived value of organic food also related to the nutrients present in the product, safety, taste and premium price. The consumer realizes the various benefits of organic nutrition, and sometimes is willing to pay a higher price for it. That is, from the perspective of perceived value, it is evident a cost-benefit relationship for the consumer, and price is not really a barrier for the 
acquisition of this type of food. Singh and Verma (2017) investigated the factors that influence the purchase of organic food by Indian consumers and, among them, the perceived price (cost-benefit) stood out, positively affecting their purchase intention.
Purchase intention of organic food

\section{Attributes of organic food}

In addition to the factors related to perceived value, literature mentions various attributes of organic food in order to understand consumer behavior. Several studies quote the health-related benefit as one of the main attributes for the consumption of organic food, as pointed by Loebnitz and Aschemann-Witzel (2016) and Thøgersen, Barcellos, Perin, and Zhou (2015). In addition to the health benefit, Thøgersen et al. (2015) highlight the importance of flavor and environmental concern in the attitude of consumers that buy organic products. Roitner-Schobesberger, Darnhofer, Somsook, and Vogl (2008) conducted a study in Bangkok, and emphasized that, along with health benefits, the demand for new, "trendy" and tastier products was an important predictor of organic food consumption. More recently, Janssen (2018) carried out a study in Germany and analyzed panel data from 9,470 households. The results suggest that aspects related to health and environmental protection positively affect the purchase of organic food, and are their main predictors.

Another relevant attribute is price (Roitner-Schobesberger, Darnhofer, Somsook, \& Vogl, 2008). Suh, Eves, and Lumbers (2015) found a negative relationship between price and consumer purchase behavior in South Korea. Lee and Yun (2015), in a survey conducted in the USA, confirmed the negative effect of organic food price on consumers' behavior. In addition, other elements stood out: nutritional content, related to the presence of nutrients, vitamins and minerals; natural content, linked to the absence of additives and artificial ingredients; ecological well-being, related to environmental concern; and sensory appeal, linked to taste, appearance and texture of organic food.

In the case of fruits and vegetables, the perceived freshness, a criterion related to sensory appeal, is one of the most important factors for buying this kind of food (Chang \& Zepeda, 2005; Shafie \& Rennie, 2012). In contrast, Costanigro, McFadden, Kroll, and Nurse (2011) and Dolezalová, Pícha, Navrátil, Veselá, and Svec (2016) argue that consumers are willing to sacrifice the taste and appearance of food in favor of attributes related to health.

To better understand the attributes identified in the literature, Table I summarizes the characteristics of organic food, the dependent variables tested, their respective studies and the type of relationship found. It shows only quantitative studies that tested the relationships between the variables of interest. Our research included all attributes present in Table I.

\begin{tabular}{|c|c|c|c|}
\hline $\begin{array}{l}\text { Attributes/ } \\
\text { independent variables }\end{array}$ & Dependent variable & Studies & Type of relationship \\
\hline \multirow[t]{3}{*}{ Benefits related to health } & Purchase attitude & $\begin{array}{l}\text { Thøgersen } \text { et al. (2015), } \\
\text { Lee and Yun (2015) }\end{array}$ & \multirow[t]{3}{*}{ Positive } \\
\hline & Purchase of organic food & Janssen (2018) & \\
\hline & Purchase intention & Zagata (2012) & \\
\hline \multirow[t]{3}{*}{ Environmental concern } & Purchase of organic food & Janssen (2018) & \multirow[t]{3}{*}{ Positive } \\
\hline & Purchase attitude & $\begin{array}{l}\text { Thøgersen et al. (2015), } \\
\text { Lee and Yun (2015) }\end{array}$ & \\
\hline & Purchase intention & Zagata (2012) & \\
\hline \multirow[t]{2}{*}{$\begin{array}{l}\text { Sensory attributes } \\
\text { (taste, appearance, etc.) }\end{array}$} & Attitude toward organic food & $\begin{array}{l}\text { Thøgersen et al. (2015), } \\
\text { Lee and Yun (2015) }\end{array}$ & \multirow[t]{2}{*}{ Positive } \\
\hline & Purchase intention & Zagata (2012) & \\
\hline \multirow[t]{2}{*}{ Price } & Attitude toward organic food & Lee and Yun (2015) & \multirow[t]{2}{*}{ Negative } \\
\hline & Purchase behavior & Suh et al. (2015) & \\
\hline
\end{tabular}

Table I. Main attributes of organic food 
REGE

26,3

202

\section{Method}

This research is a survey-type descriptive and quantitative study, and relies on the application of a structured questionnaire. It relies on a non-probabilistic convenience sampling, which resulted in a sample of 310 consumers of organic food. After data treatment, the checking of missing values and multivariate extreme cases (by Mahalanobis distance), it ended up with 247 valid cases.

Regarding the age group, 67.2 percent were between 18 and 35 years old, 66.0 percent of the sample were women, and 56.8 percent had a higher education degree. As to the frequency of purchase, 56.7 percent bought organic food at least once a week. With regard to the place of purchase, 53.1 percent bought such food in street markets, specialized stores or directly from the producer, and 45.7 percent in supermarkets.

The questionnaire had three parts. The first part had questions about the consumption of organic food, frequency and place of purchase. The second part addressed the scale items on trust, perceived value, attributes and purchase intention. We used a seven-point Likert scale, ranging from 1 (totally disagree) to 7 (totally agree). Finally, there were questions about sociodemographic issues like age, gender, education level and marital status.

The scale for measuring trust was developed by Krystallis and Chryssohoidis (2005) and Siegrist (2000), and adapted by Teng and Wang (2015). It is composed of four items, which seek to quantify consumer trust through attributes inherent to organic food. In order to check the perceived value by the consumer of organic food, we used the scale proposed by Sweeney and Soutar (2001) and adapted by Nguyen, Vu, Phan and Cao (2015) for multidimensional value measurement in food products. It has 18 items divided into four value dimensions: emotional value (4 items); social value (3 items); functional value related to the price, named economic value (4 items); and functional value related to the performance/quality of the product (7 items).

We used Lee and Yun's (2015) scale to map the attributes, which identified, in the purchase intention of organic food, those related to nutritional content, natural content, ecological well-being, sensory appeal and price. In total, there are 16 items, 4 relating to nutritional content, 3 to natural content, 4 to ecological well-being, 3 are about sensory appeal and 2 about price.

Finally, in order to identify the purchase intention, which is the dependent variable of the study, we used the scale adapted by Teng and Wang (2015), with three items.

All the four scales previously described and used in the study were submitted to a back-translation process, according to Brislin (1970). Next, we conducted both semantic and by experts validations, following Pasquali's (1999) recommendations.

As to the procedures, we developed the questionnaire on the Typeform platform and made it available online. Data collection was completed in 30 consecutive days during the second half of 2016. We spread it through several social networks and e-mail.

After data treatment, valid cases were submitted to exploratory factor analyses (EFA) and multiple linear regression analyses. Post hoc checking of statistical power followed Cohen's (1992) guidelines and identified a power $(1-\beta)$ of 0.99 , considering a medium effect size $\left(f^{2}=0.25\right)$ and a significance of $\alpha=0.05$. Results are presented in the next section.

\section{Results}

In order to achieve the research goals, we initially carried out EFAs for the constructs of attributes, perceived value, trust and purchase intention.

For the attributes and the perceived value, we accomplished the analyses using the method of principal axis factoring and direct oblimin rotation. Only factor loads above 0.45 and communalities above 0.50 were considered, following the guidelines of Lee and Hooley (2005) for marketing constructs. The EFA results for the attributes are shown in Table II. We checked the matrix factorability by the KMO index of 0.73 . To determine the 


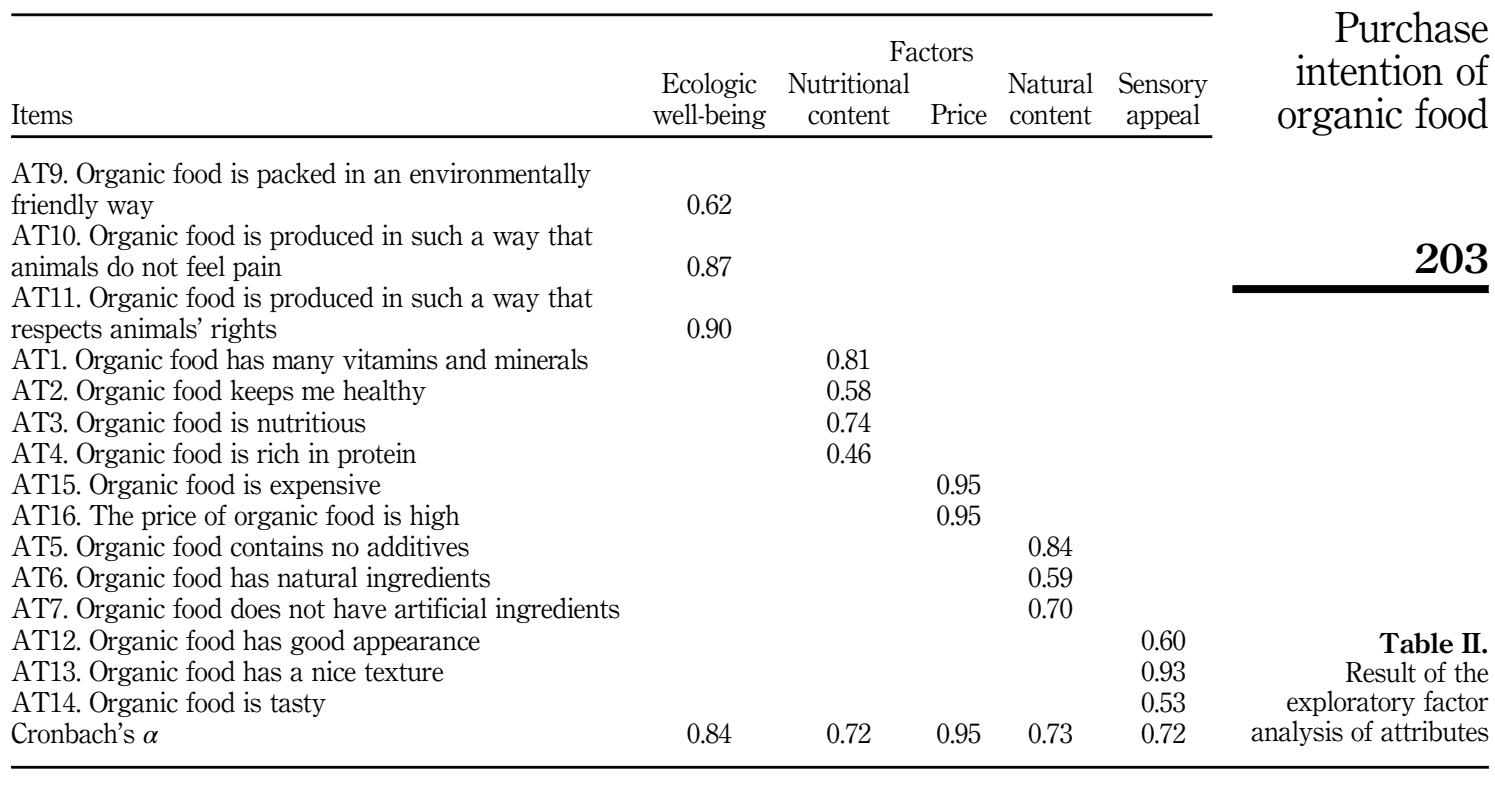

number of factors extracted, we used the Kaiser criterion (eigenvalues $>1$ ), which resulted in the retention of 5 factors, with total explained variance of 70.1 percent.

Item AT8 ("Organic food is produced in such a way that does not destabilize nature's balance") showed load duplicity for factors 1 and 3 . Thus, we removed it from the analysis. To check factors' internal reliability, we calculated their Cronbach's $\alpha$ s. All values were above 0.70, as recommended by Hair, Anderson, Tatham and Black (2005).

Table III shows EFA results for Perceived Value. KMO was 0.88, and four factors were extracted by Kaiser's criterion. Total variance explained was 68.2 percent. We calculated Cronbach's $\alpha$ s and they were above 0.70. Most items were classified as very good or excellent (Comrey and Lee, 1992).

Next, we conducted factor analyses for the trust and purchase intention constructs, through the principal axis factoring method, but without rotation, because they are both uni-factor. For the trust scale, KMO was 0.798 , with an explained variance of 75.5 percent, with one factor. Of the four original items, only item CONF1 ("I think organic food companies are aware of their responsibilities") was excluded, due to the communality below 0.50 . The Cronbach's $\alpha$ for trust was 0.93 . The factor loads of each item are described in Table IV.

For the purchase intention scale, KMO was 0.67 , with an explained variance of 74.6 percent. All items were kept, and Cronbach's $\alpha$ was 0.83 . Factor loads for each item are described in Table $\mathrm{V}$.

After checking the validity of the scales adopted for the research, we carried out several analyses of multiple linear regression in order to reach our main objective: to analyze the relationship between trust, perceived value, attributes and purchase intention of organic food. To do so, the factors corresponding to each construct were changed into indicators, by calculating the Anderson Rubin scores, used to ensure that the estimated factors are not correlated with each other (Hair, Anderson, Tatham, \& Black, 2005). Next, we observed the respective assumptions.

The multivariate extreme cases were identified by the Mahalanobis distance, and we removed 5 additional cases from the analysis. Through correlation analysis, there was no linearity between the attribute price and purchase intention (dependent variable) and no 
REGE

26,3

\section{4}

Table III. factor analysis of perceived value
Result of exploratory

\begin{tabular}{|c|c|c|c|c|}
\hline \multirow[b]{2}{*}{ Items } & \multicolumn{4}{|c|}{ Factors } \\
\hline & $\begin{array}{l}\text { Emotional } \\
\text { value }\end{array}$ & $\begin{array}{l}\text { Functional } \\
\text { value }\end{array}$ & $\begin{array}{l}\text { Economic } \\
\text { value }\end{array}$ & $\begin{array}{l}\text { Social } \\
\text { value }\end{array}$ \\
\hline VP1. Organic food is good for health & 0.59 & & & \\
\hline VP6. Organic food is tasty & 0.67 & & & \\
\hline VP12. Consuming organic food makes me feel good & 0.84 & & & \\
\hline VP13. Consuming organic food makes me want more & 0.64 & & & \\
\hline VP14. I like to consume organic food & 0.99 & & & \\
\hline VP15. I feel calm regarding the consumption of organic food & 0.64 & & & \\
\hline VP2. Organic food is well produced & & 0.61 & & \\
\hline VP3. Organic food is reliable & & 0.87 & & \\
\hline VP4. Organic food has an acceptable safety standard & & 0.87 & & \\
\hline VP5. Organic food has a consistent quality & & 0.80 & & \\
\hline VP7. Organic food has an acceptable quality standard & & 0.66 & & \\
\hline VP8. Organic food has a reasonable price & & & 0.77 & \\
\hline VP9. Organic food offers benefit for the money spent & & & 0.60 & \\
\hline VP10. Organic food is a good product regarding its price & & & 0.71 & \\
\hline VP11. Organic food is cheap compared to other products & & & 0.61 & \\
\hline VP16. Consuming organic food helps me feel socially accepted & & & & 0.67 \\
\hline $\begin{array}{l}\text { VP17. Consuming organic food makes a good impression on } \\
\text { members of my family }\end{array}$ & & & & 085 \\
\hline $\begin{array}{l}\text { VP18. Consuming organic food matches the eating culture } \\
\text { and tradition of my social circle }\end{array}$ & & & & 0.71 \\
\hline Cronbach's $\alpha$ & 0.88 & 0.88 & 0.78 & 0.82 \\
\hline
\end{tabular}

Items

Factor load

Table IV.

Result of exploratory

CONF2. I trust that someone who sells certified organic food really sells quality organic food

0.86

CONF3. I trust the quality seal of organic food

0.94

CONF4. I trust the institutions that certify organic food

other independent variables; thus, it was removed from the analysis. Data showed the presence of homoscedasticity and absence of multicollinearity (VIF < 4). However, we did not observe data normality; therefore, we adopted the technique of resampling by bootstrapping to check the regression models. The initial model is shown in Table VI, with purchase intention as the dependent variable.

The final model, with the best goodness of fit for the influence on purchase intention, resulted in the factors of emotional value, consumer trust, economic value, social value and sensory attribute, as explained in Table VII.

The emotional value presented the highest $\beta(0.690)$, followed by trust $(\beta=0.274)$ and the sensory attribute $(\beta=-0.159)$, economic value $(\beta=0.156)$ and social value $(\beta=0.149)$. The adjusted $R^{2}$ was 59.8 percent. This explanation has a great effect on purchase intention (Cohen, 1992). According to this author, 2 percent is considered a small effect, 13 percent a medium effect and 26 percent, a large effect.

Table V.

Result of exploratory factor analysis of purchase intention
Items

Load factor

INT1. If organic food were available in markets, I would buy it

INT3. The probability that I buy organic food is very high 


\begin{tabular}{|c|c|c|c|c|c|}
\hline Independent variables & $\mathrm{SE}$ & $\beta$ & $t$ & $p$-value & \\
\hline Constant & 0.040 & & 0.00 & 1.000 & ood \\
\hline Trust & 0.052 & 0.266 & 5.12 & 0.000 & \\
\hline Emotional value & 0.059 & 0.662 & 11.17 & 0.000 & \\
\hline Functional value & 0.059 & -0.009 & -0.14 & 0.886 & \\
\hline Economic value & 0.045 & 0.123 & 2.72 & 0.007 & \\
\hline Social value & 0.042 & 0.149 & 3.56 & 0.000 & 05 \\
\hline Nutritional content & 0.047 & -0.018 & -0.37 & 0.708 & \\
\hline Economic well-being & 0.048 & -0.012 & -0.24 & 0.809 & Table VI. \\
\hline Natural content & 0.055 & 0.069 & 1.24 & 0.214 & Result of multiple \\
\hline Sensorial attribute & 0.053 & -0.148 & -2.72 & 0.006 & regression analysis \\
\hline Price & 0.045 & -0.082 & -1.84 & 0.067 & (initial model) \\
\hline
\end{tabular}

\begin{tabular}{lcrrrr}
\hline Independent variables & $\mathrm{SE}$ & $\beta$ & $t$ & $p$-value & \\
\cline { 1 - 2 } Constant & 0.040 & & 0.00 & 1.000 & \\
Trust & 0.043 & 0.274 & 6.31 & 0.000 & \\
Emotional value & 0.047 & 0.690 & 14.68 & 0.000 & Table VII. \\
Economic value & 0.041 & 0.156 & 3.81 & 0.000 & Result of multiple \\
Social value & 0.040 & 0.149 & 3.68 & 0.000 & regression analysis \\
Sensory attribute & 0.047 & -0.159 & -3.36 & 0.001 & (final model) \\
\hline
\end{tabular}

\section{Discussion}

We reached several results throughout the study. Initially, regarding the sample profile, many respondents mentioned supermarkets as a place for buying organic food. This fact is in line with Guivant (2003), who mentioned the expansion of the organic food market in Brazil, which is no longer exclusive of specialized stores and street markets; supermarkets play a dominant role among supply channels.

Regarding the validity tests of the study measurements, the EFA result for attributes confirms Lee and Yun (2015), since the distribution of items in the factors was the same. Therefore, we kept the original factors' names. According to Comrey and Lee (1992), factor loads can be considered negligible (less than 0.31), poor (equal to or higher than 0.32 and up to 0.44 ), reasonable (equal or higher than 0.45 and up to 0.54 ), good (equal to or higher than 0.55 and up to 0.62 ), very good (equal to or higher than 0.63 and up to 0.70 ) and excellent (equal to or higher than 0.71). As shown in Table II, most loads are good, very good and excellent, thus indicating the validity of the measurement of attributes for the sample data.

Regarding the perceived value, we also identified the same number of factors as the scale proposed by Sweeney and Soutar (2001). As to the original scale, only two items appeared in factors other than the original scale. VP1 ("Organic food is good for health") and VP6 ("Organic food is tasty"), included in the "functional value" factor in the original scale, in our study were added to the "emotional value" factor. As Sheth, Newman and Gross (1991) explain, emotional value is achieved when purchase decision brings feelings and emotions to consumers. Thus, in consumer's perception, health concern and the taste of organic food are more related to the emotional side than to the functional side. Therefore, the result confirms the theory, and the scale indicates evidence of validity for the Brazilian context.

The same happened in the trust and purchase intention scales, both adapted by Teng and Wang (2015), and which kept good indices for sample data, in addition to the same uni-factor structure. We highlight that KMO for the purchase intention scale was slightly 
REGE 26,3

lower than indicated by literature, but the measure is promising and, even within the acceptable limit of KMO, brought relevant results to the study.

Regarding the final model identified in the study, consumers' purchase intention of organic food was strongly influenced by emotional value. This value refers to the more subjective aspects related to the sensation of pleasure and well-being associated to the consumption of organic food. In the study by Lee and Yun (2015), the hedonistic element, linked to emotional gratification and the pleasure of consuming organic food, also had a positive relationship with consumers' purchase intention. The results support several previous studies that identified the importance of the perception that organic food brings well-being (Roitner-Schobesberger et al., 2008; Loebnitz \& Aschemann-Witzel, 2016).

The second relevant factor regarding purchase intention was the consumers' trust on certification seals and certified producers. Thus, the greater the trust in a certification seal, the greater the likelihood that the product will be chosen, as identified by Janssen and Hamm (2012) and Daugbjerg and Sønderskov (2012). Tung, Shih, Wei, and Chen (2012) also attested the importance of trust for the consumption of organic food, and the lack of trust in organic agriculture processes prevents its consumption. Nuttavuthisit and Thøgersen (2017) examined the impact of subjective norms, attitude, perceived control, and trust on purchase intention by organic food consumers in Thailand. Results showed that trust plays an important role in the prediction of purchase intention, as our study suggests.

Economic value also affected purchase intention directly, and regards the financial value and cost-benefit perceived by consumers of organic foods (Nguyen, $\mathrm{Vu}, \mathrm{Phan}, \& \mathrm{Cao}, 2015)$. Consumers believe that organic food brings greater benefits for health (Ditlevsen, Sandøe, \& Lassen, 2019) and for the individual's well-being (Apaolaza, Hartmann, D'Souza, \& López, 2018). Thus, they are willing to pay a premium price for its acquisition.

Another predictor of purchase intention was social value, which regards the social acceptance of the individual by the group he/she belongs to. The result also supports the research by Nuttavuthisit and Thøgersen (2017), which proved that subjective norms affect consumer behavior. In other words, aspects related to the social relationships of consumers motivate the consumption of organic food.

Finally, there was a negative relationship between the sensory attribute and purchase intention. The result differs from other studies in which taste and appearance are attributes that positively affect purchase behavior (Chang \& Zepeda, 2005; Roitner-Schobesberger et al., 2008; Shafie \& Rennie, 2012; Thøgersen, Barcellos, Perin, \& Zhou, 2015). However, in other studies they are attributes neglected by consumers who generally choose healthier foods (Costanigro, McFadden, Kroll, \& Nurse, 2011; Dolezalová, Pícha, Navrátil, Veselá, \& Svec, 2016). One possible explanation for our result is that organic food is in general not as beautiful as conventional products, which are bigger and cleaned before being put for retail sale. Thus, the sensory attribute, linked to product appearance, can negatively affect purchase intention.

Of all factors analyzed in the study, we expected different results in the analysis. Natural and nutritional content, related to health benefits, are pointed out by several studies as predictors of the purchase of organic food (Loebnitz \& Aschemann-Witzel, 2016; Janssen, 2018). Another attribute that was not significant for the explanation of purchase intention was the price. The result differs from other studies that mentioned the negative relationship between price and consumption of these products (Lee \& Yun, 2015), and that part of the consumers cannot pay for organic products and feel that markets charge more for this kind of food (Whitehead \& Nicholson, 2001). In our sample, results suggest that the price of organic food does not affect purchase intention, since the cost-benefit (economic value) is more important for the consumer. In any case, additional studies should be conducted, mainly on the influence of health benefits and price on the behavior of organic food consumers. 


\section{Conclusions}

The objective of this study was to analyze the influence of attributes, perceived value and trust on the purchase intention of consumers of organic food. To do this, we collected data and submitted them to EFA and multiple regressions. Results indicated that emotional value, economic value, social value, trust and the sensory attribute affect purchase intention. The first was the strongest predictor, and the last emerged as a negative an unexpected result.

The study offers some academic contributions. The first is the focus on organic food. This topic, from the consumer's perspective, is not much explored in Brazil, even with the growing market for these products. The second contribution is the combination of perceived value, attributes, trust, and purchase intention in a single prediction model. And the third is the evidence of scales validity for attributes, perceived value, consumer confidence and purchase intention, regarding organic food in Brazil.

As managerial implications, our results can help strategic marketing management focused on the factors identified for the organic food market. In order to address emotional value, managers could create marketing communications that arouse the feelings and sensations of consumers and show the healthy appeal of this kind of food. As for the sensory appeal, marketing communications can increase information by highlighting the natural and healthy appearance of organic food. The evidence regarding consumer trust also shows the importance of organic products' certification and inspection.

Despite all methodological accuracy adopted in the research, we point out some limitations. Our sampling was non-probabilistic and by convenience, and the fact that most respondents were between 18 and 25 years old prevented the generalization of results. In addition, if the sample were larger, we could have conducted more advanced statistical analyses.

As suggestion for future research, we highlight the increase in the number and heterogeneity of the sample, as well as the adoption of probabilistic sampling. Scales can be improved from the results found - mainly purchase intention - which still does not present the best indices. With a wider sample, it will be possible to apply confirmatory factor analyses and use structural equation modeling. In addition to addressing consumer purchase intention, future research may seek to measure the observed purchase behavior of organic foods.

\section{References}

Aertsens, J., Mondelaers, K., Verbeke, W., Buysse, J., \& Van Huylenbroeck, G. (2011). The influence of subjective and objective knowledge on attitude, motivations and consumption of organic food. British Food Journal, 113(11), 1353-1378.

Apaolaza, V., Hartmann, P., D’Souza, C., \& López, C. M. (2018). Eat organic-feel good? The relationship between organic food consumption, health concern and subjective wellbeing. Food Quality and Preference, 63, 51-62, Available from: https://doi.org/10.1016/j.foodqual.2017.07.011

Aschemann-Witzel, J., \& Hamm, U. (2010). Do consumers prefer foods with nutrition and health claims? Results of a purchase simulation. Journal of Marketing Communications, 16(1/2), 47-58, doi: 10.1080/13527260903342746

Bamberg, S., \& Möser, G. (2007). Twenty years after Hines, Hungerford, and Tomera: a new metaanalysis of psycho-social determinants of pro-environmental behaviour. Journal of Environmental Psychology, 27(1), 14-25, Available from: http://dx.doi.org/10.1016/j.jenvp.2006.12.002

Barrett, H. R., Browne, A. W., Harris, P. J. C., \& Cadoret, K. (2002). Organic certification and the UK market: organic imports from developing countries. Food Policy, 27(4), 301-318.

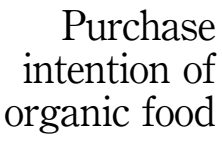

207 
REGE

26,3

Brislin, R. W. (1970). Back-translation for cross-cultural research. Journal of Cross-cultural Psychology, 1(3), 185-216.

Chang, H. S., \& Zepeda, L. (2005). Consumer perceptions and demand for organic food in Australia: focus group discussions. Renewable Agriculture and Food Systems, 20(3), $155-167$.

Cohen, J. (1992). A power primer. Psychological Bulletin, 112(1), 155-159, Available from: http://dx.doi.org/10.1037/0033-2909.112.1.155

Comrey, A. L., \& Lee, H. B. (1992), A First Course in Factor Analysis (2nd ed.). NJ and New York, NY: Lawrence Erlbaum Associates.

Costanigro, M., McFadden, D. T., Kroll, S., \& Nurse, G. (2011). An in-store valuation of local and organic apples: the role of social desirability. Agribusiness, 27(4), 465-477.

Cronin, J. J., Brady, M. K., \& Hult, C. T. M. (2000). Assessing the effects of quality, value, and customer satisfaction on consumer behavioral intentions in service environments. Journal of Retailing, 76(2), 193-218.

Daugbjerg, C., \& Sønderskov, K. M. (2012). Environmental policy performance revisited: designing effective policies for green markets. Political Studies, 60(2), 399-418. Available from: http://dx.doi.org/10.1111/j.1467-9248.2011.00910

Diallo, M. F. (2012). Effects of store image and store brand price-image on store brand purchase intention: application to an emerging market. Journal of Retailing and Consumer Services, 19(3), 360-367.

Ditlevsen, K., Sandøe, P., \& Lassen, J. (2019). Healthy food is nutritious, but organic food is healthy because it is pure: the negotiation of healthy food choices by Danish consumers of organic food. Food Quality and Preference, 71, 46-53, doi: 10.1016/j.foodqual.2018.06.001

Dolezalová, H., Pícha, K., Navrátil, J., Veselá, M., \& Svec, R. (2016). Perception of quality in decision making regarding purchase of organic food. Calitatea, 17(153), 86-91.

Ghalandari, K., \& Norouzi, A. (2012). The effect of country of origin on purchase intention: the role of product knowledge. Research Journal of Applied Sciences, Engineering and Technology, 4(9), 1166-1171.

Guivant, J. S. (2003). Os supermercados na oferta de alimentos orgânicos: apelando ao estilo de vida EGO-TRIP. Ambiente \& Sociedade, 6(2), 63-81.

Hair, J. F., Anderson, R. E., Tatham, R. L., \& Black, W. C. (2005), Análise Multivariada de dados, Bookman, Porto Alegre.

Hoppe, A., Vieira, L. M., \& Barcellos, M. D. d. (2013). Consumer behaviour towards organic food in Porto Alegre: an application of the theory of planned behaviour. Revista de Economia e Sociologia Rural, 51(1), 69-90.

Hsu, S.-Y., Chang, C. C., \& Lin, T. T. (2016). An Analysis of purchase intentions toward organic food on health consciousness and food safety with/under structural equation modeling. British Food Journal, 118(1), 200-216, Available from: https://doi.org/10.1108/ ER-09-2015-0181

Iyer, P., Davari, A., \& Paswan, A. (2016), Green products: altruism, economics, price fairness and purchase intention. Social Business, 6(1), 39-64.

Janssen, M. (2018). Determinants of organic food purchases: evidence from household panel data. Food Quality and Preference, 68(1) 19-28.

Janssen, M., \& Hamm, U. (2012). Product labelling in the market for organic food: consumer preferences and willingness-to-pay for different organic certification logos. Food Quality and Preference, 25(1), 9-22, doi: 10.1016/j.foodqual.2011.12.004

Kohlraush, A. K., Campos, L. M. d. S., \& Selig, P. M. (2004, October 27-29). Selos ambientais: qual seu papel e influência no processo de compra de produtos orgânicos. Proceedings of the $24^{\circ}$ Encontro Nacional de Engenharia de Produção[ENEGEP], Florianópolis. 
Krystallis, A., \& Chryssohoidis, G. (2005). Consumers' willingness to pay for organic food: factors that affect it and variation per organic product type. British Food Journal, 107(5), 320-343.

Lee, H., \& Yun, Z. (2015). Consumers' perceptions of organic food attributes and cognitive and affective attitudes as determinants of their purchase intentions toward organic food. Food Quality and Preference, 39, 259-267.

Lee, N., \& Hooley, G. (2005). The evolution of "classical mythology" within marketing measure development. European Journal of Marketing, 39(3/4), 365-385.

Liang, R. (2016). Predicting intentions to purchase organic food: the moderating effects of organic food prices. British Food Journal, 118(1), 183-199.

Loebnitz, N., \& Aschemann-Witzel, J. (2016). Communicating organic food quality in China: consumer perceptions of organic products and the effect of environmental value priming. Food Quality and Preference, 50, 102-108, Available from: https://doi.org/10.1016/j.foodqual.2016.02.003

Maichum, K., Parichatnon, S., \& Peng, K. (2017). The influence of attitude, knowledge and quality on purchase intention towards Halal food: a case study of young non-Muslim consumers in Thailand. International Journal of Management \& Social Sciences, 6(3), 354-364, Available from: https://doi.org/10.18178/ijssh.2017.7.5.844

Mainardes, E. W., Araujo, D. V. B. D., Lasso, S., \& Andrade, D. M. (2017). Influences on the intention to buy organic food in an emerging market. Marketing Intelligence \& Planning, 35(7), 858-876.

Marian, L., \& Thøgersen, J. (2013). Direct and mediated impacts of product and process characteristics on consumers' choice of organic vs. conventional chicken. Food Quality and Preference, 29(2), 106-112, Available from: https://doi.org/10.1016/j.foodqual.2013.03.001

Machado, D., \& Viana, D. J. (2011). Biotecnologias cooperativismo e desenvolvimento sustentável: o exemplo da Coopaflora no município de Turvo - PR. Revista Eletrônica do Curso de Ciências Sociais da Faculdade Guarapuava, 1(1), 125-127.

Moorman, C., Zaltman, G., \& Deshpandé, R. (1992). Relationships between providers and users of market research: the dynamics of trust within and between organizations. Journal of Marketing Research, 29(3), 314-328.

Nandi, R., Bokelmann, W., Gowdru, N. V., \& Dias, G. (2016). Consumer motives and purchase preferences for organic food products: empirical evidence from a consumer survey in Bangalore, South India. Journal of International Food \& Agribusiness Marketing, 28(1), 74-99, Available from: https://doi.org/10.1080/08974438.2015.1035470

Nguyen, T. N., Vu, P. A., Phan, T. T. H., \& Cao, T. K. (2015). An exploratory investigation into customer perceived value of food products in Vietnam. International Business Research, 8(12), 1.

Nocella, G., \& Kennedy, O. (2012). Food health claims - what consumers understand. Food Policy, 37(5), 571-580, Available from: http://dx.doi.org/10.1016/j.foodpol.2012.06.001

Nuttavuthisit, K., \& Thøgersen, J. (2017). The importance of consumer trust for the emergence of a market for green products: the case of organic food. Journal of Business Ethics, 140(2), 323-337, doi: 10.1007/s10551-015-2690-5

Pasquali, L. (1999). Instrumentos psicológicos: manual prático de elaboração. LabPAM/IBAPP, Brasília, p. 306.

Peattie, K. (2010). Green consumption: behavior and norms. Annual Review of Environment and Resources, 35, 195-228.

Pivato, S., Misani, N., \& Tencati, A. (2008). The impact of corporate social responsibility on consumer trust: the case of organic food. Business Ethics: A European Review, 17(1), 3-12, doi: 10.1111/j.1467-8608.2008.00515.

Rana, J., \& Paul, J. (2012). Consumer behavior and purchase intention for organic food. Journal of Consumer Marketing, 29(6), 412-422.

Roitner-Schobesberger, B., Darnhofer, I., Somsook, S., \& Vogl, C. R. (2008). Consumer perceptions of organic foods in Bangkok, Thailand. Food Policy, 33(2), 112-121.

\section{Purchase intention of organic food}


REGE 26,3

Sánchez-Fernández, R., \& Iniesta-Bonillo, M. Á. (2007). The concept of perceived value: a systematic review of the research. Marketing Theory, 7(4), 427-451.

Shafie, F. A., \& Rennie, D. (2012). Consumer perceptions towards organic food. Procedia - Social and Behavioral Sciences, 49, 360-367.

Shaharudin, M. R., Pani, J. J., Mansor, S. W., \& Elias, S. J. (2010). Purchase intention of organic food: perceived value overview. Canadian Social Science, 6(1), 70-79.

Sheth, J. N., Newman, B. I., \& Gross, B. L. (1991). Why we buy what we buy: a theory of consumption values. Journal of Business Research, 22(2), 159-170, doi: 10.1016/0148-2963(91)90050-8

Siegrist, M. (2000). The influence of trust and perceptions of risks and benefits on the acceptance of gene technology. Risk Analysis, 20(2), 195-204.

Singh, A., \& Verma, P. (2017). Factors influencing Indian consumers' actual buying behavior towards organic food products. Journal of Cleaner Production, 167, 473-483.

Sirdeshmukh, D., Singh, J., \& Sabol, B. (2002). Consumer trust, value, and loyalty in relational exchanges. Journal of Marketing, 66(1), 15-37, doi: 10.1509/jmkg.66.1.15.18449

Slater, S. F., \& Narver, J. C. (2000). Intelligence generation and superior customer value. Journal of the Academy of Marketing Science, 28(1), 120-127, doi: 10.1177/0092070300281011

Sønderskov, K. M., \& Daugbjerg, C. (2011). The state and consumer confidence in eco-labeling: organic labeling in Denmark, Sweden, the United Kingdom and the United States. Agriculture and Human Values, 28(4), 507-517.

Suh, B. W., Eves, A., \& Lumbers, M. (2015). Developing a model of organic food choice behavior. Social Behavior and Personality, 43(2), 217-230.

Sweeney, J. C., \& Soutar, G. N. (2001). Consumer perceived value: the development of a multiple item scale. Journal of Retailing, 77(2), 203-220.

Teng, C. C., \& Wang, Y. M. (2015). Decisional factors driving organic food consumption: generation of consumer purchase intentions. British Food Journal, 117(3), 1066-1081.

Thøgersen, J., Barcellos, M. D., Perin, M. G., \& Zhou, Y. (2015). Consumer buying motives and attitudes towards organic food in two emerging markets: China and Brazil. International Marketing Review, 32(3/4), 389-413.

Tung, S. J., Shih, C. C., Wei, S., \& Chen, Y. H. (2012). Attitudinal inconsistency toward organic food in relation to purchasing intention and behavior: an illustration of Taiwan consumers. British Food Journal, 114(7), 997-1015, Available from: https://doi.org/10.1108/00070701211241581

Whitehead, P., \& Nicholson, S. (2001). Organic food: niche or mainstream. Institute of Grocery Distribution, Watford.

Wilcock, A., Pun, M., Khanona, J., \& Aung, M. (2004). Consumer attitudes, knowledge and behaviour: a review of food safety issues. Trends in Food Science \& Technology, 15(2), 56-66, Available from: http://dx.doi.org/10.1016/j.tifs.2003.08.004

Willer, H., \& Lernoud, J. (2016), The world of organic agriculture, statistics and emerging trends 2016, (1st ed.). FIBL, IFOAM Handbook, Available from: http://orgprints.org/31151/1/willerlernoud-2016-world-of-organic.pdf (accessed April 2016)

Yadav, R., \& Pathak, G. S. (2016). Intention to purchase organic food among young consumers: evidences from a developing nation. Appetite, 96, 122-128, Available from: https://doi.org/10.1016/j.appet.2015.09.017

Yin, S., Wu, L., Du, L., \& Chen, M. (2010). Consumers' purchase intention of organic food in China. Journal of the Science of Food and Agriculture, 90(8), 1361-1367, doi: 10.1002/jsfa.3936.

Zagata, L. (2012). Consumers' belief and behavioral intentions towards organic food: evidence from Czech Republic. Appetite, 59(1), 81-89.

Zeithaml, V. A. (1988). Consumer perceptions of price, quality, and value: a means-end model and synthesis of evidence. Journal of Marketing, 52(3), 2-22, doi: 10.2307/1251446 


\section{Further reading}

Research Institute of Organic Agriculture (FiBL) and International Federation of Organic Agriculture Moviment (IFOAM) (2015). The world organic agriculture: statistics and emerging trends 2015. Available from: www.fibl.org/fileadmin/documents/shop/1663-organic-world-2015.pdf (accessed April 2016).
Purchase intention of organic food

\section{Corresponding author}

Isabelle Cristina Galindo Curvelo can be contacted at: isabellegcurvelo@usp.br

Associate Editor: Adriana Marotti de Mello

For instructions on how to order reprints of this article, please visit our website: 